Concept Paper

\title{
Three Anchoring Managerial Mechanisms to Embed Sustainability in Service Organizations
}

\author{
Carlos Martin-Rios*(D), Cédric Poretti and Giovanni Battista Derchi
}

check for updates

Citation: Martin-Rios, C.; Poretti, C.; Derchi, G.B. Three Anchoring

Managerial Mechanisms to Embed

Sustainability in Service

Organizations. Sustainability 2022, 14 , 265. https://doi.org/10.3390/ su14010265

Academic Editor: Colin Michael Hall

Received: 6 December 2021

Accepted: 23 December 2021

Published: 27 December 2021

Publisher's Note: MDPI stays neutral with regard to jurisdictional claims in published maps and institutional affiliations.

Copyright: (C) 2021 by the authors. Licensee MDPI, Basel, Switzerland. This article is an open access article distributed under the terms and conditions of the Creative Commons Attribution (CC BY) license (https:// creativecommons.org/licenses/by/ $4.0 /)$.
EHL Hospitality Business School, HES-SO University of Applied Sciences and Arts Western Switzerland, 1000 Lausanne, Switzerland; cedric.poretti@ehl.ch (C.P.); giovanni-battista.derchi@ehl.ch (G.B.D.)

* Correspondence: carlos.martin-rios@ehl.ch; Tel.: +41-21-785-1111

Keywords: sustainable business model; sustainability innovation; corporate information disclosure; reporting; accountability; CSR disclosure; sustainability management control; circular economy business models; service sector; service sustainability

\section{Introduction}

Service organizations ought to adapt their offering and governance to the principles of sustainability. The 2015 Paris accord requires countries, industries, and individual companies to commit themselves to a target of net-zero carbon emissions by 2050. Accordingly, the European Union and countries such as the US, Japan, and Korea have pledged to cut carbon dioxide $\left(\mathrm{CO}_{2}\right)$ emissions between $40 \%$ and $60 \%$ by 2030 . Although with different levels of transparency and accountability, a myriad of prominent companies has followed suit. For example, Microsoft, Moderna, and Amazon have pledged to be carbon negative by 2030 [1]. Some service businesses have also made sustainability commitments, such as Royal Caribbean Cruises, that aims to deliver a net zero cruise ship by 2035 [2]. McDonald's and its nearly 40,000 restaurants around the world targets cutting global GHG emissions to net zero by 2050 while lowering absolute emissions by about a third for both its suppliers by 2030 [3]. United Airlines has launched "Eco-Skies Alliance," a partnership with global firms such as Nike and Siemens AG to finance and use 3.4 million gallons of low-carbon, sustainable aviation fuel derived from trash in 2021 [4].

Commitment to these climate change targets will produce unpredictable changes for entire industries and individual businesses [5]. A recent report from a leading investment bank suggests that "only companies that overhaul their business models and change profoundly will be fit for the transition" [6]. Although there has been higher attention to certain industrial activities, such as mobility, energy, and transportation, services are also at the center of the debate. This is, particularly, the case for tourism and hospitality [7], 
financial and commercial banking [8], and retailers and food [9]. A recent study by a large consulting firm shows that "service sectors such as professional services and information and communications must double the pace of emissions reduction in this decade, and then accelerate another $50 \%$ to $70 \%$ in the following 10 years to be on track for net-zero emissions in their operations by 2050" [10].

Commitment to tackling societal grand challenges greatly shapes businesses' level of engagement and sophistication in generating sustainability management solutions. The literature has illustrated some of the opportunities and challenges that service firms face in order to reduce emissions, embrace sustainability principles, and even to adopt specific sustainability actions. For the most part, services have adopted voluntary, more or less specific practices mostly toward environmental concerns, such as reducing single use plastic [11], energy use and conservation [12], or the adoption of certain circular economy activities, including recycling activities, redesigning services, and water usage [13]. At the system level, a limited number of prominent service firms are reporting carbon footprint and offsetting [14], aligning their strategies and practices with SDGs [15], and adopting environmental labeling certifications [16].

There is, however, a limited number of service firms engaged in transforming their businesses to move towards system-wide sustainability transitions. The adoption of sustainability principles at the system or business model-level brings in a level of managerial complexity and uncertainty that, currently, most service companies feel ill-equipped to handle. One of the biggest challenges that service firms face is their transition to more sustainable businesses. Specifically, the main research question that this study addresses is: to what extent and how can services be considered as drivers of innovation, by means of integrating social concerns, and long-term financial and environmental priorities at all levels in their business model, internal control system, and external reporting and accountability?

The urgency to address the grand challenges faced by societies highlights the necessity to understand and assess the change capacity of service firms. Notwithstanding the availability of specific sustainability implementation frameworks, the service sector must make considerable effort towards the system-wide adoption of environmental and social sustainability priorities. While partly based on existing theoretical and empirical research, this discussion paper sets the debate in the wider context of the organizational literature on sustainability transitions and explicitly takes into consideration the currently understudied needs and demands of the service industry. Specifically, this discussion paper revolves around three key anchoring managerial mechanisms that service firms must use to embed sustainability principles and practices and to manage growth and transition to a sustainable service economy (Figure 1). First, an overview of the specificities and determinants of CSR reporting is provided, followed by a discussion of the challenges and opportunities of shaping the future of CSR reporting. Second, the challenges and opportunities for service firms of embedding sustainability into service businesses will be reviewed. Two important elements are taken into consideration: the adoption of sustainable business models and the implementation of sustainability innovation and management. Finally, key major management control issues that relate to the implementation of sustainability strategy are identified and illustrated in accordance with extant research in sustainability and management control. Major issues for organizations entail the managing of employees' motivation towards more sustainable behavior, sustainability performance measurement, and the need to make trade-offs and balance the multiple and often contrasting sustainability goals.

The main contribution of this discussion paper is to discuss existing research on service sustainability transitions by means of a multidisciplinary perspective on key external and internal management factors. It addresses a series of questions regarding the sustainability transition of service companies based upon an extensive interdisciplinary literature review. The following pages contribute to enriching the debate by delving into a conceptual analysis of three core mechanisms to tackle societal grand challenges and furnish service companies with real-world sustainability management solutions. Each section also provides concluding remarks and lines of future inquiry. 


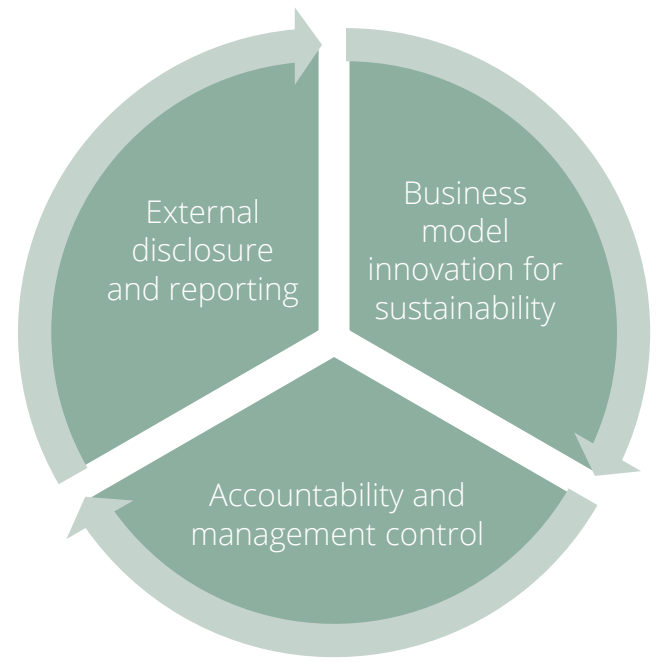

Figure 1. Three anchoring mechanisms to embed sustainability in services.

\section{The Adoption of Sustainability in Services: External and Internal Anchoring Mechanisms}

\subsection{External Mechanisms: Corporate Information Disclosure and CSR Reporting}

One of the main motivations underlying corporate information disclosure is to reduce information asymmetry between the company and outsiders, which is crucial for companies to attract and retain investors, but also to maintain and improve reputation. In a world where companies are under pressure to be accountable for their socioenvironmental footprint, sustainability reports have been gaining in importance [17-20]. Most companies reporting about their Corporate Social Responsibility (CSR hereafter) activities do it to signal their achievements, while some use CSR reports as a greenwashing mechanism [21-24].

\subsubsection{CSR Reporting Specificities and Determinants}

CSR reporting differs from financial reporting in several ways: (1) it focuses on information that is more heterogenous and targets a wider spectrum of user, (2) it is not exclusively focused on the core business of the firm, (3) it is hard to quantify in monetary terms, and (4) it is generally done on a voluntary basis. These different features show how challenging it is to standardize CSR disclosures and highlight the importance of adopting a global reporting framework such as the Global Reporting Initiatives (GRI) or Sustainability Accounting Standards Board (SASB) standards.

The GRI provides a best practice impact reporting framework, which is used by the majority of the largest firms [25-28]. While this type of framework was initially supposed to increase the credibility and comparability of CSR reports, various studies document that it is often used inconsistently [29] and opportunistically, either for social legitimation or impression management purposes [30-36]. Moreover, given the voluntary nature of CSR reporting, the propensity of firms to disclose information varies greatly across contexts.

The literature documents that CSR disclosures are influenced by both firm-specific characteristics and external pressures. Regarding firm-specific factors, CSR reporting is positively associated with firm size, ownership structure, corporate governance, and management-specific characteristics. Indeed, larger companies are more scrutinized and, thus, tend to disclose CSR information in a higher quantity and of better quality (e.g., [37-39]). Furthermore, the greater the ownership dispersion, the higher the likelihood that the firm discloses information [40]. In other words, the greater the information asymmetry and the larger the pool of investors with whom the firm needs to communicate, the more likely it is to report about CSR activities. In addition, Dalla Via and Perego [41] document that, the stronger the level of corporate governance, the more likely it is that the firm will disclose CSR information, which is in line with Mallin et al. [42], who find 
a positive association between stakeholder-orientation and CSR reporting. Next, as explained by Christensen et al. [43], CSR reporting is positively associated with managers' education [44], opinions (e.g., [45,46]), ethnicity [47], confidence [48], and expertise [49]. Finally, industry-specific characteristics play a major role in explaining voluntary disclosure. Indeed, firms in industries that are perceived as unethical or unsustainable (alcohol, tobacco, oil, or firearms) disclose more on their actions than other firms [50], mainly for legitimization purposes.

For what concerns external incentives, stakeholders' pressure has been shown to have a strong impact on information disclosure [51], such as shareholder activism [52]. Various studies highlight that institutional investors are especially likely to put pressure on companies to enhance transparency regarding CSR activities [53,54]. In addition, standard setters, politics, and governments also play a key role in influencing CSR reporting [55-57].

\subsubsection{Mandatory CSR Reporting}

Given the underlying role of CSR reporting in informing firms' stakeholders, making it mandatory will increase its credibility and transparency, and enhance the comparison of firms' CSR actions. However, due to the high level of heterogeneity in CSR practices, it will also increase complexity and create incremental costs. Business activities vary tremendously across companies, and so does the materiality of such activities. Providing firms with flexibility in terms of reporting might be necessary to allow them to disclose informative content, while it might lead to compliance issues. Consequently, the real benefits related to reporting harmonization should occur within industries, which would make it easier to compare CSR activities from one company to the next.

In some countries (e.g., the U.S.), firms are prohibited from omitting material information in their filings [43]. Assuming that, effectively, companies do not withhold material CSR information, the real effect of mandating CSR disclosures would then not be to provide new material information to stakeholders, but rather to enhance comparability across companies. However, such an assumption appears tenuous. Various studies show that companies are usually not transparent with regards to disclosing material CSR information (e.g., [49,58]). Consequently, imposing CSR standards may, in all likelihood, reduce such information asymmetry.

\subsubsection{Sustainability Assurance}

Non-financial disclosures are increasingly popular; thus, the need for an external independent verification is becoming crucial to ensure a minimum level of accuracy, credibility, and transparency [24,59], and to mitigate greenwashing concerns [60]. Consequently, a set of clear standards are required, involving information that must be verifiable, and thus audited. Given the heterogeneity and the specificity of CSR information, auditing such information is far from a trivial endeavor. In some cases, it might involve scientific knowledge (e.g., measuring pollution levels, health impact, etc.) that auditors (most of the time) do not have access to. Given that the current market for sustainability assurance is not yet subject to strict regulations [61], it is not dominated by big players such as the Big Four companies. Instead, accounting firms appear to be 'holding their own' against non-accounting assurance providers (e.g., consulting firms, NGOs), leading to significant differences in terms of assurance process and expertise, which raises the question of the quality of the assurance provided.

Prior studies document mixed results regarding the association of CSR performance and external assurance demand. For instance, Alon and Vidovic [23] and Clarkson et al. [62] showed that higher CSR performers are associated with a higher propensity to have their CSR report audited, while Braam et al. [63] found that poorer environmental performance leads to a higher likelihood of demanding external assurance in specific contexts. In other words, it is not clear yet whether good performers have a higher propensity to demand an audit because they disclose true and verifiable information and want it to be explicit, and/or whether poor performers want to distance themselves from greenwashers by having 
their CSR report (including potentially unverifiable boilerplate information) audited [24], or both. In any case, mandating an audit of CSR reports would solve this issue (every listed company would have to have its CSR report audited), while the question related to audit quality would remain.

\subsubsection{Current Challenges and Future Research Directions}

Among the major challenges underlying sustainability reporting, is that it is becoming crucial for companies to develop the ability to collect and measure data in a timely and efficient way, while management teams need to be inclined to disclose sensitive/controversial information in a transparent way (balanced report) [20]. Digital information management tools are important to disseminate information to stakeholders in a way that is both timely and consistent with their needs. Indeed, sustainability is a continuous issue that contrasts with the lagging nature of reporting. For this reason, CSR reports will need to be complemented by more dynamic/interactive communication tools [20].

Given the heterogeneity of service firms activities and strategies [64-66], and, consequently, the potential wide range of underlying CSR activities, developing tailor-made reporting standards (i.e., industry-specific), or at least providing some flexibility to adapt general standards to the company's activities, seems necessary to avoid compliance and over-complexity issues. Moreover, Casado-Diaz et al. [67] show that the disclosure of CSR activities for service firms leads to higher investor reactions than for firms that make products, which also highlights the importance of making sure that CSR disclosures by service firms are not only aimed at developing a positive image by feeding stakeholders with what they want to hear (i.e., greenwashing). Indeed, the purpose of CSR reporting goes further than simply being a tool for brand development, it should be part of a credible, reliable, and timely mosaic of information for stakeholders about the true societal and environmental impacts of the firm's activities. Further studies could analyze the propensity of firms in specific service sub-sectors to disclose verifiable information, and also investigate whether CSR reports' audit quality varies across these sub-sectors depending on the companies' ownership structure, governance, and/or institutional features. Last but not least, a wider approach and definition of CSR information materiality in the service industry needs to be developed, one that accounts for the whole spectrum of companies' stakeholders.

\subsection{Internal Mechanisms: System-Level Transformation of Business Models}

This section addresses the challenges and opportunities that service firms face when incorporating sustainability into their business by means of system-level transformation of their business model and/or adoption of sustainability innovation and management. A sustainable business model can be defined as "a business model that creates, delivers, and captures value for all its stakeholders without depleting the natural, economic, and social capital it relies on" [68] (p. 4).

\subsubsection{Sustainable Business Models}

Different mainstream theories, namely stakeholder theory, legitimacy theory, institutional theory, and signaling theory, offer different economic, social, and institutional explanatory interpretations of the changing forces involved in sustainability management becoming an imperative for organizations [69]. Introducing sustainability innovations in the firm's business model attempts to provide them with greater adaptive capacity and sustainable ways of doing business [70].

Current research illustrates alternative pathways to create business model innovations that enhance sustainability [71]. However, research suggests that the service sector still falls behind transforming their businesses and adopting novel managerial practices. One common motive is the lack of strategic leeway, particularly in labor-intensive service activities [72]. A long tradition of research has highlighted the uniqueness of services in adopting a more strategic mindset. For example, Thomas [73] stated that there is a 
consensus among academics and experts that the service industry activity is big on tactics but light on strategy.

For the most part, service firms face two main organizational challenges. First, they tend to struggle to create sustainable business model innovation and conceptualize/implement sustainable business models. Sustainable business models require sustainability innovations to propel systemic change at the strategic, managerial, and operational levels [74]. New business models and value propositions are holistic and leverage the social, financial, and environmental impact of the business at multiple levels: the company itself, the local, regional, and national communities of interest, the industry in which it operates, its competitors, allies, and suppliers, and, finally, social and institutional stakeholders, including customers, groups of interest, and society at large [75]. As Geissdoerfer et al. [76] suggest, "This can comprise the development of entirely new business models, the diversification into additional business models, the acquisition of new business models, or the transformation from one business model to another".

Table 1 shows three frameworks or types of sustainable business model innovation. Each framework is tied to a specific ambition, involves different opportunities and risks, and requires attention to resource management. These frameworks could guide service firms' management teams during their business model innovation process by identifying the scope, opportunities, risks, resources, and timeline. Given the lack of research tailored to services, each of these elements points to areas where future studies can address this important aspect of the implementation of sustainable business models and derive strategic implications.

Table 1. Overview of strategies of sustainable business model innovation, based on Geissdoerfer et al. [76].

\begin{tabular}{|c|c|c|c|c|c|}
\hline Framework & Scope & Opportunities & Risks & $\begin{array}{l}\text { Resource } \\
\text { Intensity }\end{array}$ & Plan \\
\hline $\begin{array}{l}\text { Transform } \\
\text { existing business } \\
\text { model }\end{array}$ & $\begin{array}{l}\text { Changing existing } \\
\text { business model }\end{array}$ & $\begin{array}{ll}\text { - } & \text { Adjustment } \\
\text { - } & \text { Revision } \\
\text { - } & \text { Transformation }\end{array}$ & $\begin{array}{ll}\text { - } & \text { Resistance } \\
\text { - } & \text { Multi- } \\
& \text { stakeholder } \\
& \text { conflict }\end{array}$ & $\begin{array}{l}\text { Existing } \\
\text { resources }\end{array}$ & Shorter-term \\
\hline $\begin{array}{l}\text { Diversify } \\
\text { existing business } \\
\text { model }\end{array}$ & $\begin{array}{l}\text { Creating } \\
\text { additional } \\
\text { business model }\end{array}$ & $\begin{array}{ll}\text { - } & \text { Exploration } \\
\text { - } & \text { Redesign } \\
\text { - } & \text { Development }\end{array}$ & $\begin{array}{ll}\text { - } & \text { Cost } \\
\text { - } & \text { Long-term } \\
\text { - } & \text { Conflict of } \\
& \text { interest }\end{array}$ & $\begin{array}{l}\text { Existing and new } \\
\text { resources }\end{array}$ & Longer-term \\
\hline $\begin{array}{l}\text { Acquire } \\
\text { additional } \\
\text { business models }\end{array}$ & $\begin{array}{l}\text { Integrating } \\
\text { external business } \\
\text { model }\end{array}$ & $\begin{array}{l}\text { - } \text { Improvement } \\
\text { - Adjustment } \\
\text { - Adoption }\end{array}$ & $\begin{array}{ll}\text { - } & \text { Cost } \\
\text { - } & \text { Integration } \\
& \text { conflict } \\
\text { - } & \text { Overlap }\end{array}$ & $\begin{array}{l}\text { Existing and new } \\
\text { resources }\end{array}$ & Shorter term \\
\hline
\end{tabular}

Different frameworks or types of business model are transformed into explicit implementation strategies. Ritala et al. [77] have proposed nine "archetypes" or generic sustainable business models. Each archetype places emphasis on certain distinctive purposes and implementation strategies, including major environmental innovations around the maximization of material and energy efficiency; closing existing resource loops; substituting existing processes with renewables and natural processes. Major social innovations are related to the delivery of functionality instead of ownership; adopting a stewardship role; encouraging sufficiency. Finally, economic innovations contain repurposing and upcycling for society and the environment; fostering inclusive value creation; developing sustainable scale-up solutions. Each archetype includes more or less wide-ranging guidance on how to transform business models toward sustainability. 


\subsubsection{Circular Economy Business Models}

Recent studies have advanced specific frameworks to redefine how businesses rethink their supply chains and value propositions, specifically the implementation of circular economy business models [78,79]. The circular economy is a socio-technical transition from the dominant linear economy model to a transformative, restorative, and regenerative economy by means of a "regenerative system in which resource input and waste, emission, and energy leakage are minimized by slowing, closing, and narrowing material and energy loops. This can be achieved through long-lasting design, maintenance, repair, reuse, remanufacturing, refurbishing, and recycling" [80] (p. 759).

For example, Lüdeke-Freund et al. [81] propose several patterns to adopt circular economy business models, including a specific focus on repairing, reusing, refurbishing, recycling, repurposing, and using organic feedstock. Moreover, De Jesus et al. [82] present a framework for pro-circular innovation strategies and conclude that the main driving forms of innovation linked to design, manufacturing, logistics, and end-of-life management are innovations related to recycling and recovery, and innovations connecting supply and demand.

\subsubsection{Sustainability Practices}

Finally, there is a considerable amount of research in organizational and management studies on how to define, measure, and assess sustainability and the different sustainability innovations and practices for services. For example, Lozano [83] provides an analysis of different voluntary tools, approaches, and initiatives to engage with sustainability based on 16 of the most widely used initiatives, including "life cycle assessment, eco-design, cleaner production, corporate social responsibility, and sustainability reporting" (p. 982). Gunasekaran and Spalanzani [84] compared sustainability practices in manufacturing and services for sustainable business development. There is a growing number of studies on sustainability practices in banking, consulting, foodservice, transportation, tourism, and hospitality [85-88]. Specifically, scholars have shown how to integrate sustainability innovations in key practices and operations, such as managing and reducing waste, energy consumption, recyclability practices, or implementing green supply chains [12,89-91].

\subsubsection{Current Challenges and Future Research Directions}

Different business model patterns and circular innovation strategies imply redefining all major business model dimensions. In introducing sustainable business models, service firms can greatly benefit from addressing the need to close resource flows and adopt a circular economy business model. Given the lack of studies devoted to service activities, each circular innovation strategy and pattern proposed opens up interesting venues for future research. Likewise, different theoretical models and archetypes proposed by the literature offer firms in different service activities guidance on how to innovate their business model toward sustainability [76,77]. Whether and how retailers, technology service providers, consulting firms, or tourism activities transform their business models to close resource loops, deliver functionality, or encourage sufficiency are areas where future research is needed. Although research on sustainable business models is exploding, there is still an absence of evidence-based research on how different types of business models are transformed into explicit implementation strategies tailored to service providers. This is one of the biggest current challenges that services are confronting, and one that deserves more science-based and evidence-based research interest.

At the operational and implementation level, the link between sustainability initiatives and sustainable business models remains unclear [7]. In the services realm, there are few empirical studies examining adaptation and transformation processes to generate business value at the economic, social, and environmental levels. There is a clear lack of research on the different sustainability practices and solutions that may contribute to building up the business model for sustainability in the services industry. 


\subsection{Internal Mechanisms: Management Control and Governance}

This section focuses on the challenges and opportunities for service firms to embed sustainability into service business by means of internal sustainability management control and governance mechanisms [92].

\subsubsection{Issues in Sustainability Management Control}

Sustainability control is considered a key driver of organizations' transition towards more sustainable business models. It supports sustainability strategy and influences the behaviors of organizational actors towards its goals [93-95]. More specifically, it refers to the use of planning and control systems and procedures (e.g., strategic planning, budgeting, costing, internal reporting, and performance measurement, evaluation, and rewarding) by which managers assure that resources are obtained and used effectively and efficiently to achieve the organization's objectives [96]. Accordingly, an emerging body of empirical research and many corporate examples show that sustainability control systems help managers build and implement sustainability strategies by providing key information that support multi-criteria decision-making [97] and drives the motivation of managers and employees to achieve sustainability goals $[97,98]$.

While extant research explores the transformative potential of sustainability control systems, empirical evidence on how these control systems are used and the extent to which they translate into organizational change is lacking $[99,100]$. Although there are an increasing number of academic studies on sustainability control, many relevant questions remain largely unanswered. These include how organizations design or adapt their planning and control practices to support decision making that produces substantial improvement in social and environmental performance; how managers can balance financial goals and the multiple sustainability goals effectively over time; how to measure sustainability performance congruently and accurately [97].

Based on key notions from the extant literature in sustainability and management control, in this study, we identify three major control issues that relate to the implementation of sustainability strategy at the organization level. Additionally, for each control issue identified, we recognize areas for fruitful future research.

\subsubsection{Motivation}

The first control issue refers to how the use of formal management control systems (i.e., compensation plans) risk undermining individual motivation to achieve results. Arguably, the extant literature shows that managers and employees perform tasks under the influence of two types of motivation: the intrinsic motivation driven by the willingness to accomplish their work, and the extrinsic motivation driven by formal incentives that provide rewards in exchange for their effort [101]. Additionally, intrinsic and extrinsic motivations are proven to interact, with this interaction potentially affecting the achievement of performance results [101,102]. In particular, some studies argue that extrinsic motivation linked to formal incentive systems could crowd out the effect of intrinsic motivation, creating a negative effect on performance conditional on the intensity of the crowding-out effect [102]. In the field of sustainability management, social goals are often associated with the intrinsic motivation of individuals [103]. As a result, the use of formal control systems, such as monetary bonuses, could affect the influence of intrinsic motivation linked to social behaviors and could therefore be associated with reduced overall performance [103]. On the contrary, other studies look at psychological factors such as wage equity, social preferences, and teamwork (e.g., [104,105]), and argue that monetary incentives have a positive effect on intrinsic motivation by increasing the frequency of the rewarded behaviors and therefore produce enhanced performance [106].

Linked to motivation, there is the question of how to set up targets for social and environmental goals. Based on Locke and Latham [107,108], target difficulty is positively associated with individual performance, as it increases both effort intensity and duration, until goals become excessively difficult. Moreover, target attainment is likely to motivate 
individuals to exert effort when searching for efficiencies and thinking "outside-the-box" as they explore original and better ways to reach the challenging targets [108-110]. Given the greater complexity of setting objectives and challenging social and environmental performance targets, the validity of these arguments remains, to a large extent, an open question in a sustainability setting. An exception is the work of Ioannou et al. [111], which shows that firms setting more difficult targets or providing monetary incentives are able to complete higher percentages of their targets. Moreover, they found that the combined use of ambitious targets and monetary incentives negatively affect the level of target completion.

\subsubsection{Performance Measures}

The second control issue refers to the measurability of sustainability performance. As previously mentioned, sustainability performance includes not only environmental aspects (e.g., reducing carbon footprint), but also social aspects (e.g., fighting modern slavery, providing local communities with access to water). Prior research shows that environmental and social aspects differ in terms of their measurability properties [111,112].

On the one hand, organizations tend to use environmental performance metrics that rely on scientific evidence and procedures on how to measure environmental impact. For example, initiatives such as the Global Reporting Initiative and the Greenhouse Gas (GHG) Protocol provide standardized methodologies to enable an organization to quantify the environmental impact of its carbon emissions, water usage, and energy consumption [113]. Organizations have, therefore, a relatively rich set of environmental metrics that are standardized, objective, and likely to be employed as credible and rigorous targets. Accordingly, in the last decade, a growing number of organizations have been adopting science-based targets to reduce carbon emissions in accordance with limiting global temperature increases to less than $2{ }^{\circ} \mathrm{C}$ above pre-industrial levels, based on the 2015 Paris Agreement [114]. Nevertheless, many environmental metrics suffer from controllability issues, particularly for individual managers and employees responsible for environmental decisions and actions who struggle to evaluate and monitor environmental metrics. Given the influence of externalities on an organization's environmental performance, the influenceability of environmental metrics through an individual's action can remain limited, hindering the contractibility, or contractual clarity, of these metrics for performance evaluation $[111,112,115,116]$.

On the other hand, organizations still lack a widely accepted set of objective standards for social performance metrics that capture the multiple relationships with their stakeholders. Current measurement proposals often combine objective and subjective procedures and include metrics with unclear signal-to-noise ratios and uncertainty regarding their potential for manipulation [113]. In line with this evidence, prior work $[113,117]$ argues that the design of social performance metrics is still a work in progress, with managers and scholars exploring various options yet struggling to reach consensus. As such, some studies contend that measuring social performance is more difficult than environmental performance, with lower consensus and standardization raising concerns regarding the verifiability and contractibility of these metrics and, thereby, explaining (in part) the reduced integration in management control systems [111-113].

Prior work also examined the managerial and performance implications of using environmental and social metrics in control systems $[111,113,117,118]$. In particular, some studies distinguish substantive and symbolic uses of environmental and social metrics, showing different effects on sustainability performance [118].

\subsubsection{Multiplicity of Tasks}

The third control issue refers to the multiplicity of decisions and actions that achieving sustainability goals requires. To implement a sustainability strategy, the board of directors and, in turn, executive managers, should delegate the responsibility of improving sustainability performance across the organizational hierarchy [119]. As corporate sustainability includes different aspects, delegation often entails assigning managers and employees with 
multiple tasks with potentially incongruent goals and needing a long-time horizon for implementation $[120,121]$. As a result, multiple and competing goals combined with resource scarcity make effort allocation difficult for managers and employees [117,122]. This implies that managers and employees must trade off among the multiple tasks assigned, giving preference (at least in the short term) to some goals whose outcomes are beneficial to a certain group of stakeholders at the expense of others [123].

In this context, contingent conditions such as the pressure to reach financial objectives and the influence of certain organizational and individual factors (such as organizational culture, managers' entrenchment, and career advancement requirements) may affect managers' effort and resource allocation decisions. This could eventually lead to biased decisions that do not yield sufficient sustainability performance improvements [123]. In line with this argument, Flammer et al. [118] show that managers tend to focus their attention more on those stakeholders who have a short-term effect on financial performance (i.e., consumers and employees), rather than on those who do not have an immediate effect on financial performance, (i.e., natural environment and local communities).

The effective design of control systems (e.g., capital budgeting and compensation plans) should address this concern and encourage managers and employees to allocate effort "optimally" among the multiple tasks assigned [122].

\subsubsection{Current Challenges and Future Research Directions}

As a result of the contrasting arguments in relation to the first control issue-the relationship between the use of formal management control systems and individual motivation, evidence remains inconclusive on the role of control systems to motivate managers and employees in services to pursue sustainability goals. In particular, little is known about the intensity of the motivational power needed by formal control systems to compensate for the negative crowding-out effect on intrinsic motivation and to produce a substantive positive effect. It seems crucial for academic scholars and business leaders to expand their knowledge of the design properties of control systems for service companies when it comes to motivating managers and employees to implement a sustainability strategy. As for the second control issue - the measurability of sustainability performance, service organizations have a number of metrics to assess sustainability performance both in environmental aspects and social aspects Yet, little is known regarding their measurement properties (verifiability, controllability, and congruence), which managers in services would need for substantive governance reforms. Finally, the third control issue emphasizes the multiplicity of decisions and actions involved in sustainability goals' achievement. Yet, extant literature provides no sufficient guidance regarding how to design management control systems that mitigate biases in effort and resource allocation while contributing to the effective implementation of sustainability strategy in services. These open questions represent fascinating areas to pursue in future research.

\section{Conclusions}

It is of the utmost importance to tackle society's 'grand challenges' and encourage firms in the service industry to transition to a more sustainable business model. This requires new managerial tools to forge a new mindset, for which not all service companies are fully equipped with the necessary best practices or have access to the knowledge that they require. This paper intends to contribute to the literature on service firms and sustainability by analyzing three anchoring mechanisms that can be deployed to embed sustainability principles and practices in service organizations.

First, CSR information has specificities that make it heterogenous, difficult to verify, and hard to quantify. While it is generally disclosed on a voluntary basis, its credibility appears to be a significant issue. Understanding the determinants of firms' CSR information disclosure, and adapting the reporting framework, is crucial for standard setters to evolve towards a more globalized reporting context, making information reliable and comparable across companies. Taking the firm's perspective, it is also crucial to understand 
stakeholders' (updated) expectations, as well as what is considered as material from a stakeholder's point of view. Indeed, new trends and standards will require companies to adapt quickly to a dynamic and ever-changing environment. Moreover, service companies will have to develop and acquire digital tools as well as internal expertise, allowing them to report/disseminate specific, relevant, and measurable information on a timely basis. Besides the company-stakeholders' relationship, an independent third party is needed to provide assurance regarding the information disclosed, namely auditors. As a result, the external assurance market is also quickly evolving and plays a prominent role in making audited CSR information reliable. However, greater standardization of audit processes and auditors' expertise is required to reach this goal.

Second, management and innovation systems and practices are constantly being reviewed, developed, and updated. Specifically, the adoption of sustainable business models and the implementation of sustainability innovation and management are shown to play a key role in steering sustainability transitions in service firms [71]. This transition implies the professionalization of management in certain service activities. It also requires the adoption of formal innovation strategies that embed sustainability principles in the management and delivery of services [124].

Finally, we identify three major management control issues that make the implementation of sustainability strategy complex for service organizations and, thus, often hamper its effectiveness. Sustainability control systems (e.g., strategic planning, budgeting, costing, internal reporting, and performance measurement, evaluation, and rewarding) are crucial to promote the transformation of services towards sustainability [93] as they provide key information for improved decision-making [97] and drive management behavior towards achieving environmental and social goals $[97,98]$. Yet, service companies encounter difficulties in integrating sustainability aspects into organizational processes and management decisions [125], with motivational power, performance measurement, and a multiplicity of goals being major barriers. In particular, the use of monetary variable compensation tied to specific sustainability goals could produce adverse effects if the intrinsic motivation of employees is crowded out [101]. Setting up challenging yet motivating targets for sustainability goals is no easy feat, yielding often to lower performance improvement [108]. In addition, measuring environmental and social performances would require a wide set of objective standards that accurately assess the impact on the natural environmental and the quality of the multiple relationships with stakeholders. However, differences in measurability across a large set of metrics and low standardization raise concerns regarding their verifiability and contractibility, leading to reduced integration [111-113]. Finally, sustainability decision-making is tough as it often requires trading (at least in the short-term) the multiple environmental and social activities off. Yet, the design of control systems such as capital budgeting and incentives rarely helps management allocate, over time, resources and effort "efficiently" across the multiple and potentially incongruent sustainability goals.

\section{Managerial Implications}

This paper has important managerial implications. First, while the introduction of mandatory CSR reporting may have some benefits, it might also have unexpected detrimental managerial implications. As explained by Gatti et al. [126], if companies have the obligation to disclose CSR information, it may reduce management's "involvement in the definition and design of CSR programs" (p. 963), favoring reactivity over proactivity [127]. As a consequence of a reduced engagement in CSR by managers, the overall CSR strategy becomes at risk of being inefficient. Moreover, for CSR programs to have effective social and environmental impacts, business leaders will have to go beyond expectations. Companies will need to recruit well-trained CSR-oriented managers who are able to communicate with a variety of stakeholders. The companies that will stand out will be the most creative and proactive ones, which in turn will prove to be the best strategy to succeed both from a societal and a financial point of view. Second, the field of sustainable business models and sustainability innovation highlights the priorities that can be expected to foster a sustain- 
ability transition for service firms. Services must embrace business model patterns and circular innovation strategies tailored to their specific needs and priorities [128]. Managers in these companies need to acknowledge the fact that services face a turning point in sustainability management as incremental innovations are no longer enough to deliver the scale of transformation required [129]. Finally, building effective ways to motivate managers and employees can represent a key driver for continuous improvement in the areas of corporate sustainability, especially once law-hanging fruits are harvested and it becomes more difficult for organizations to find new patterns to substantial enhancement [130]. The management of service companies, and, more generally, of other organizations, will benefit significantly from gaining a better understanding of key trade-offs and measurement properties of environmental and social performances. Main benefits of improved performance sustainability measurement and identification of significant trade-offs are twofold. On the one hand, managers will be able to design performance measurement systems that are more informative and focus their attention on main priorities, thus leading to more effective decision-making and timely actions distributed over time. On the other hand, managers shall build systems that estimate and measure their effort and results with greater accuracy, enabling a more meaningful performance evaluation and mitigating manipulation of results [113].

In conclusion, deepening the conceptual roots of sustainability in service firms by identifying the key mechanisms to cope with external demands and the internal dimensions of management control, governance, and innovation are the critical factors that service firms need to address. We hope that this paper can be of interest and value to the service management research community and that it may lead to empirical tests on the importance of adopting external and internal company-level mechanisms of transparency, accountability, and innovation to prompt system-level adoption of sustainability in service organizations.

Author Contributions: The authors contributed equally to this work. All authors have read and agreed to the published version of the manuscript.

Funding: This research received no external funding.

Institutional Review Board Statement: Not applicable.

Informed Consent Statement: Not applicable.

Data Availability Statement: Data used were publicly available; no identifying information was collected or included. All the data used in this research was accessed through Web of Science Core Collection (WoSCC) bibliographic database.

Conflicts of Interest: The authors declare no conflict of interest.

\section{References}

1. Mytton, D. Hiding greenhouse gas emissions in the cloud. Nat. Clim. Chang. 2020, 10, 701. [CrossRef]

2. Scott, D.; Gössling, S. Destination net-zero: What does the international energy agency roadmap mean for tourism? J. Sustain. Tour. 2021, 30, 1-18. [CrossRef]

3. Langert, B. The Battle To Do Good: Inside McDonald's Sustainability Journey; Emerald Group Publishing: Bingley, UK, 2019.

4. Forum, W.E. Powering Sustainable Aviation through Consumer Demand: The Clean Skies for Tomorrow; World Economic Forum: Cologny, France, 2021.

5. Eccles, R.G.; Ioannou, I.; Serafeim, G. The impact of corporate sustainability on organizational processes and performance. Manag. Sci. 2014, 60, 2835-2857. [CrossRef]

6. Odier, L. Building portfolios around Eagles to deliver superior returns for our clients. Lomb. Odier 2019. Available online: https:/ / www.lombardodier.com/ostrich_eagle (accessed on 22 December 2021).

7. Raub, S.P.; Martin-Rios, C. “Think sustainable, act local”-A stakeholder-filter-model for translating SDGs into sustainability initiatives with local impact. Int. J. Contemp. Hosp. Manag. 2019, 31, 2428-2447. [CrossRef]

8. Miralles-Quirós, M.M.; Miralles-Quirós, J.L.; Redondo Hernández, J. ESG performance and shareholder value creation in the banking industry: International differences. Sustainability 2019, 11, 1404. [CrossRef]

9. Raimo, N.; de Nuccio, E.; Giakoumelou, A.; Petruzzella, F.; Vitolla, F. Non-financial information and cost of equity capital: An empirical analysis in the food and beverage industry. Br. Food J. 2020, 123, 49-65. [CrossRef]

10. Accenture. Reaching NetZero by 2050; Accenture: Dublin, Ireland, 2021. 
11. Wagner, T.P. Reducing single-use plastic shopping bags in the USA. Waste Manag. 2017, 70, 3-12. [CrossRef] [PubMed]

12. Raggio, R.D.; Ekman, P.; Thompson, S.M. Making energy metrics relevant to service firms: From energy conservation to energy productivity. J. Clean. Prod. 2020, 256, 120493. [CrossRef]

13. Katz-Gerro, T.; López Sintas, J. Mapping circular economy activities in the European Union: Patterns of implementation and their correlates in small and medium-Sized enterprises. Bus. Strategy Environ. 2019, 28, 485-496. [CrossRef]

14. Duff, A. Corporate social responsibility reporting in professional accounting firms. Br. Account. Rev. 2016, 48, 74-86. [CrossRef]

15. Centobelli, P.; Cerchione, R.; Esposito, E. Pursuing supply chain sustainable development goals through the adoption of green practices and enabling technologies: A cross-country analysis of LSPs. Technol. Forecast. Soc. Chang. 2020, 153, 119920. [CrossRef]

16. He, D.; Ren, S.; Zeng, H. Environmental labeling certification and firm environmental and financial performance: A resource management perspective. Bus. Strategy Environ. 2021. [CrossRef]

17. Brown, J.; Dillard, J. Integrated reporting: On the need for broadening out and opening up. Account. Audit. Account. J. 2014, 27, 1120-1156. [CrossRef]

18. Park, J.; Brorson, T. Experiences of and views on third-party assurance of corporate environmental and sustainability reports. $J$. Clean. Prod. 2005, 13, 1095-1106. [CrossRef]

19. Rasche, A.; Esser, D.E. From stakeholder management to stakeholder accountability. J. Bus. Ethics 2006, 65, 251-267. [CrossRef]

20. Safari, M.; Areeb, A. A qualitative analysis of GRI principles for defining sustainability report quality: An Australian case from the preparers' perspective. In Accounting Forum; Routledge: London, UK, 2020; pp. 344-375.

21. Clarkson, P.M.; Li, Y.; Richardson, G.D.; Vasvari, F.P. Revisiting the relation between environmental performance and environmental disclosure: An empirical analysis. Account. Organ. Soc. 2008, 33, 303-327. [CrossRef]

22. Mahoney, L.S.; Thorne, L.; Cecil, L.; LaGore, W. A research note on standalone corporate social responsibility reports: Signaling or greenwashing? Crit. Perspect. Account. 2013, 24, 350-359. [CrossRef]

23. Alon, A.; Vidovic, M. Sustainability performance and assurance: Influence on reputation. Corp. Reput. Rev. 2015, 18, 337-352. [CrossRef]

24. Koseoglu, M.A.; Uyar, A.; Kilic, M.; Kuzey, C.; Karaman, A.S. Exploring the connections among CSR performance, reporting, and external assurance: Evidence from the hospitality and tourism industry. Int. J. Hosp. Manag. 2021, 94, 102819. [CrossRef]

25. De Villiers, C.; Rinaldi, L.; Unerman, J. Integrated Reporting: Insights, gaps and an agenda for future research. Account. Audit. Account. J. 2014, 27, 1042-1067. [CrossRef]

26. Haller, A.; van Staden, C. The value added statement-An appropriate instrument for Integrated Reporting. Account. Audit. Account. J. 2014, 27, 1190-1216. [CrossRef]

27. Higgins, C.; Stubbs, W.; Love, T. Walking the talk(s): Organisational narratives of integrated reporting. Account. Audit. Account. J. 2014, 27, 1090-1119. [CrossRef]

28. King, A.; Bartels, W.; McKenzie, M.; Austin, E. Currents of Change: The KPMG Survey of Corporate Responsibility Reporting 2015; KPMG: Rotterdam, The Netherlands, 2015.

29. Guthrie, J.; Farneti, F. GRI sustainability reporting by Australian public sector organizations. Public Money Manag. 2008, 28, 361-366. [CrossRef]

30. Campbell, D. Intra-and intersectoral effects in environmental disclosures: Evidence for legitimacy theory? Bus. Strategy Environ. 2003, 12, 357-371. [CrossRef]

31. Deegan, C. Introduction: The legitimising effect of social and environmental disclosures-A theoretical foundation. Account. Audit. Account. J. 2002, 15, 282-311. [CrossRef]

32. Deegan, C. Insights from legitimacy theory. In Sustainability, Accounting and Accountability; Routledge: London, UK, 2007.

33. Hahn, R.; Lülfs, R. Legitimizing negative aspects in GRI-oriented sustainability reporting: A qualitative analysis of corporate disclosure strategies. J. Bus. Ethics 2014, 123, 401-420. [CrossRef]

34. Manetti, G. The quality of stakeholder engagement in sustainability reporting: Empirical evidence and critical points. Corp. Soc. Responsib. Environ. Manag. 2011, 18, 110-122. [CrossRef]

35. Cho, C.H.; Roberts, R.W.; Patten, D.M. The language of US corporate environmental disclosure. Account. Organ. Soc. 2010, 35, 431-443. [CrossRef]

36. Talbot, D.; Boiral, O. Strategies for climate change and impression management: A case study among Canada's large industrial emitters. J. Bus. Ethics 2015, 132, 329-346. [CrossRef]

37. Hahn, R.; Kühnen, M. Determinants of sustainability reporting: A review of results, trends, theory, and opportunities in an expanding field of research. J. Clean. Prod. 2013, 59, 5-21. [CrossRef]

38. Cormier, D.; Magnan, M. Environmental reporting management: A continental European perspective. J. Account. Public Policy 2003, 22, 43-62. [CrossRef]

39. Thorne, L.; Mahoney, L.S.; Manetti, G. Motivations for issuing standalone CSR reports: A survey of Canadian firms. Account. Audit. Account. J. 2014, 27, 686-714. [CrossRef]

40. Höllerer, M.A. From taken-for-granted to explicit commitment: The rise of CSR in a corporatist country. J. Manag. Stud. 2013, 50, 573-606. [CrossRef]

41. Dalla Via, N.; Perego, P. Determinants of conflict minerals disclosure under the Dodd-Frank Act. Bus. Strategy Environ. 2018, 27, 773-788. [CrossRef] 
42. Mallin, C.; Michelon, G.; Raggi, D. Monitoring intensity and stakeholders' orientation: How does governance affect social and environmental disclosure? J. Bus. Ethics 2013, 114, 29-43. [CrossRef]

43. Christensen, H.B.; Hail, L.; Leuz, C. Adoption of CSR and Sustainability Reporting Standards: Economic Analysis and Review; Financial Working Paper; ECGI: Brussels, Belgium, 2019.

44. Lewis, B.W.; Walls, J.L.; Dowell, G.W. Difference in degrees: CEO characteristics and firm environmental disclosure. Strateg. Manag. J. 2014, 35, 712-722. [CrossRef]

45. Adams, C.A.; McNicholas, P. Making a difference: Sustainability reporting, accountability and organisational change. Account. Audit. Account. J. 2007, 20, 382-402. [CrossRef]

46. Parker, L.D. Corporate social accountability through action: Contemporary insights from British industrial pioneers. Account. Organ. Soc. 2014, 39, 632-659. [CrossRef]

47. Haniffa, R.M.; Cooke, T.E. The impact of culture and governance on corporate social reporting. J. Account. Public Policy 2005, 24, 391-430. [CrossRef]

48. McCarthy, S.; Oliver, B.; Song, S. Corporate social responsibility and CEO confidence. J. Bank. Financ. 2017, 75, 280-291. [CrossRef]

49. Peters, G.F.; Romi, A.M. The association between sustainability governance characteristics and the assurance of corporate sustainability reports. Auditing 2015, 34, 163-198. [CrossRef]

50. Gamerschlag, R.; Möller, K.; Verbeeten, F. Determinants of voluntary CSR disclosure: Empirical evidence from Germany. Rev. Manag. Sci. 2011, 5, 233-262. [CrossRef]

51. Watson, L. Corporate social responsibility research in accounting. J. Account. Lit. 2015, 34, 1-16.

52. Reid, E.M.; Toffel, M.W. Responding to public and private politics: Corporate disclosure of climate change strategies. Strateg. Manag. J. 2009, 30, 1157-1178. [CrossRef]

53. Dhaliwal, D.S.; Li, O.Z.; Tsang, A.; Yang, Y.G. Voluntary nonfinancial disclosure and the cost of equity capital: The initiation of corporate social responsibility reporting. Account. Rev. 2011, 86, 59-100. [CrossRef]

54. Solomon, J.F.; Solomon, A.; Norton, S.D.; Joseph, N.L. Private climate change reporting: An emerging discourse of risk and opportunity? Account. Audit. Account. J. 2011, 24, 1119-1148. [CrossRef]

55. Doonan, J.; Lanoie, P.; Laplante, B. Determinants of environmental performance in the Canadian pulp and paper industry: An assessment from inside the industry. Ecol. Econ. 2005, 55, 73-84. [CrossRef]

56. Delmas, M.A.; Toffel, M.W. Organizational responses to environmental demands: Opening the black box. Strateg. Manag. J. 2008, 29, 1027-1055. [CrossRef]

57. Innes, R.; Sam, A.G. Voluntary pollution reductions and the enforcement of environmental law: An empirical study of the 33/50 program. J. Law Econ. 2008, 51, 271-296. [CrossRef]

58. Grewal, J.; Hauptmann, C.; Serafeim, G. Material sustainability information and stock price informativeness. J. Bus. Ethics 2021, 171, 513-544. [CrossRef]

59. Jones, P.; Hillier, D.; Comfort, D. Sustainability in the hospitality industry: Some personal reflections on corporate challenges and research agendas. Int. J. Contemp. Hosp. Manag. 2016, 28, 36-67. [CrossRef]

60. Font, X.; Walmsley, A.; Cogotti, S.; McCombes, L.; Häusler, N. Corporate social responsibility: The disclosure-performance gap. Tour. Manag. 2012, 33, 1544-1553. [CrossRef]

61. Channuntapipat, C.; Samsonova-Taddei, A.; Turley, S. Variation in sustainability assurance practice: An analysis of accounting versus non-accounting providers. Br. Account. Rev. 2020, 52, 100843. [CrossRef]

62. Clarkson, P.; Li, Y.; Richardson, G.; Tsang, A. Causes and consequences of voluntary assurance of CSR reports: International evidence involving Dow Jones Sustainability Index Inclusion and Firm Valuation. Account. Audit. Account. J. 2019, 32, $2451-2474$. [CrossRef]

63. Braam, G.J.; de Weerd, L.U.; Hauck, M.; Huijbregts, M.A. Determinants of corporate environmental reporting: The importance of environmental performance and assurance. J. Clean. Prod. 2016, 129, 724-734. [CrossRef]

64. Malhotra, N.; Morris, T. Heterogeneity in professional service firms. J. Manag. Stud. 2009, 46, 895-922. [CrossRef]

65. Poretti, C.; Blal, I. The asset-light strategies and the dividend puzzle: International evidence from the hospitality industry. Int. J. Hosp. Manag. 2020, 91, 102639. [CrossRef]

66. Poretti, C.; Heo, C.Y. Asset-light strategies and stock market reactions to COVID-19's pandemic announcement: The case of hospitality firms. Tour. Econ. 2021, 13548166211005198. [CrossRef]

67. Casado-Díaz, A.B.; Nicolau-Gonzálbez, J.L.; Ruiz-Moreno, F.; Sellers-Rubio, R. The differentiated effects of CSR actions in the service industry. J. Serv. Mark. 2014, 27, 558-565. [CrossRef]

68. Schaltegger, S.; Hansen, E.; Lüdeke-Freund, F. Business models for sustainability: Origins, present research, and future avenues (Editorial). Organ. Environ. 2016, 29, 3-10. [CrossRef]

69. Boons, F.; Lüdeke-Freund, F. Business models for sustainable innovation: State-of-the-art and steps towards a research agenda. J. Clean. Prod. 2013, 45, 9-19. [CrossRef]

70. Hall, J.; Wagner, M. Integrating sustainability into firms' processes: Performance effects and the moderating role of business models and innovation. Bus. Strategy Environ. 2012, 21, 183-196. [CrossRef]

71. Bolton, R.; Hannon, M. Governing sustainability transitions through business model innovation: Towards a systems understanding. Res. Policy 2016, 45, 1731-1742. [CrossRef] 
72. Castellacci, F. Technological paradigms, regimes and trajectories: Manufacturing and service industries in a new taxonomy of sectoral patterns of innovation. Res. Policy 2008, 37, 978-994. [CrossRef]

73. Thomas, D.R. Strategy is different in service businesses. Harv. Bus. Rev. 1978, 56, 158-165.

74. Lüdeke-Freund, F.; Dembek, K. Sustainable business model research and practice: Emerging field or passing fancy? J. Clean. Prod. 2017, 168, 1668-1678. [CrossRef]

75. Evans, S.; Vladimirova, D.; Holgado, M.; Van Fossen, K.; Yang, M.; Silva, E.A.; Barlow, C.Y. Business model innovation for sustainability: Towards a unified perspective for creation of sustainable business models. Bus. Strategy Environ. 2017, 26, 597-608. [CrossRef]

76. Geissdoerfer, M.; Vladimirova, D.; Evans, S. Sustainable business model innovation: A review. J. Clean. Prod. 2018, 198, 401-416. [CrossRef]

77. Ritala, P.; Huotari, P.; Bocken, N.; Albareda, L.; Puumalainen, K. Sustainable business model adoption among S\&P 500 firms: A longitudinal content analysis study. J. Clean. Prod. 2018, 170, 216-226.

78. Rizos, V.; Behrens, A.; Van der Gaast, W.; Hofman, E.; Ioannou, A.; Kafyeke, T.; Flamos, A.; Rinaldi, R.; Papadelis, S.; HirschnitzGarbers, M. Implementation of circular economy business models by small and medium-sized enterprises (SMEs): Barriers and enablers. Sustainability 2016, 8, 1212. [CrossRef]

79. Prieto-Sandoval, V.; Jaca, C.; Ormazabal, M. Towards a consensus on the circular economy. J. Clean. Prod. 2018, 179, 605-615. [CrossRef]

80. Geissdoerfer, M.; Savaget, P.; Bocken, N.M.; Hultink, E.J. The Circular Economy-A new sustainability paradigm? J. Clean. Prod. 2017, 143, 757-768. [CrossRef]

81. Lüdeke-Freund, F.; Gold, S.; Bocken, N. A Review and Basic Typology of Circular Economy Business Model Patterns. J. Ind. Ecol. 2018, 23, 36-61. [CrossRef]

82. De Jesus, A.; Lammi, M.; Domenech, T.; Vanhuyse, F.; Mendonça, S. Eco-Innovation Diversity in a Circular Economy: Towards Circular Innovation Studies. Sustainability 2021, 13, 10974. [CrossRef]

83. Lozano, R. Towards better embedding sustainability into companies' systems: An analysis of voluntary corporate initiatives. $J$. Clean. Prod. 2012, 25, 14-26. [CrossRef]

84. Gunasekaran, A.; Spalanzani, A. Sustainability of manufacturing and services: Investigations for research and applications. Int. J. Prod. Econ. 2012, 140, 35-47. [CrossRef]

85. Font, X.; Garay, L.; Jones, S. Sustainability motivations and practices in small tourism enterprises in European protected areas. $J$ Clean. Prod. 2016, 137, 1439-1448. [CrossRef]

86. Høgevold, N.M.; Svensson, G.; Wagner, B.; Petzer, D.J.; Klopper, H.B.; Varela, J.C.S.; Padin, C.; Ferro, C. Sustainable business models: Corporate reasons, economic effects, social boundaries, environmental actions and organizational challenges in sustainable business practices. Balt. J. Manag. 2014, 9, 357-380. [CrossRef]

87. Kiron, D.; Unruh, G.; Reeves, M.; Kruschwitz, N.; Rubel, H.; ZumFelde, A.M. Corporate sustainability at a crossroads. MIT Sloan Manag. Rev. 2017, 58. Available online: https://sloanreview.mit.edu/projects/corporate-sustainability-at-a-crossroads/ (accessed on 22 December 2021).

88. Raut, R.; Cheikhrouhou, N.; Kharat, M. Sustainability in the banking industry: A strategic multi-criterion analysis. Bus. Strategy Environ. 2017, 26, 550-568. [CrossRef]

89. Frey, M.; Iraldo, F.; Testa, F. The determinants of innovation in green supply chains: Evidence from an Italian sectoral study. RD Manag. 2013, 43, 352-364. [CrossRef]

90. Martin-Rios, C.; Demen-Meier, C.; Gössling, S.; Cornuz, C. Food waste management innovations in the foodservice industry. Waste Manag. 2018, 79, 196-206. [CrossRef]

91. Martin-Rios, C.; Hofmann, A.; Mackenzie, N. Sustainability-oriented innovations in food waste management technology. Sustainability 2021, 13, 210. [CrossRef]

92. Albertini, E. The contribution of management control systems to environmental capabilities. J. Bus. Ethics 2019, 159, 1163-1180. [CrossRef]

93. Gond, J.-P.; Grubnic, S.; Herzig, C.; Moon, J. Configuring management control systems: Theorizing the integration of strategy and sustainability. Manag. Account. Res. 2012, 23, 205-223. [CrossRef]

94. Henri, J.-F.; Journeault, M. Eco-control: The influence of management control systems on environmental and economic performance. Account. Organ. Soc. 2010, 35, 63-80. [CrossRef]

95. Kaplan, R.; McMillan, D. Reimagining the Balanced Scorecard for the ESG Era. Harv. Bus. Rev. 2021, 3. Available online: https://hbr.org/2021/02/reimagining-the-balanced-scorecard-for-the-esg-era (accessed on 22 December 2021).

96. Anthony, R.N. Planning and Control Systems: A Framework for Analysis; Division of Research, Graduate School of Business Administration: Harvard, MA, USA, 1965.

97. Joshi, S.; Li, Y. What is corporate sustainability and how do firms practice it? A management accounting research perspective. J. Manag. Account. Res. 2016, 28, 1-11. [CrossRef]

98. Ditillo, A.; Lisi, I.E. Exploring sustainability control systems' integration: The relevance of sustainability orientation. J. Manag. Account. Res. 2016, 28, 125-148. [CrossRef]

99. Martin-Rios, C. Innovation in organisational control systems: Toward greater accountability. Int. J. Bus. Perform. Manag. 2015, 16, 373-388. [CrossRef] 
100. Martin-Rios, C. Organizational control rationales in knowledge-Intensive organizations: An integrative review of emerging trends. J. Public Aff. 2018, 18, e1695. [CrossRef]

101. Ryan, R.M.; Deci, E.L. Self-determination theory and the facilitation of intrinsic motivation, social development, and well-being. Am. Psychol. 2000, 55, 68. [CrossRef] [PubMed]

102. Frey, B.S.; Jegen, R. Motivation crowding theory. J. Econ. Surv. 2001, 15, 589-611. [CrossRef]

103. Bénabou, R.; Tirole, J. Individual and corporate social responsibility. Economica 2010, 77, 1-19. [CrossRef]

104. Gerhart, B.; Rynes, S.L.; Fulmer, I.S. 6 pay and performance: Individuals, groups, and executives. Acad. Manag. Ann. 2009, 3, 251-315. [CrossRef]

105. Larkin, I.; Pierce, L.; Gino, F. The psychological costs of pay-for-performance: Implications for the strategic compensation of employees. Strateg. Manag. J. 2012, 33, 1194-1214. [CrossRef]

106. Skinner, B.F. Science and Human Behavior; Simon and Schuster: New York, NY, USA, 1965.

107. Locke, E.A.; Latham, G.P. A Theory of Goal Setting $\mathcal{E}$ Task Performance; Prentice-Hall, Inc: Hoboken, NJ, USA, 1990.

108. Locke, E.A.; Latham, G.P. Building a practically useful theory of goal setting and task motivation: A 35-year odyssey. Am. Psychol. 2002, 57, 705. [CrossRef] [PubMed]

109. Bonner, S.E.; Sprinkle, G.B. The effects of monetary incentives on effort and task performance: Theories, evidence, and a framework for research. Account. Organ. Soc. 2002, 27, 303-345. [CrossRef]

110. Shalley, C.E. Effects of coaction, expected evaluation, and goal setting on creativity and productivity. Acad. Manag. J. 1995, 38, 483-503.

111. Ioannou, I.; Li, S.X.; Serafeim, G. The effect of target difficulty on target completion: The case of reducing carbon emissions. Account. Rev. 2016, 91, 1467-1492. [CrossRef]

112. Chatterji, A.K.; Durand, R.; Levine, D.I.; Touboul, S. Do ratings of firms converge? Implications for managers, investors and strategy researchers. Strateg. Manag. J. 2016, 37, 1597-1614. [CrossRef]

113. Berrone, P.; Gomez-Mejia, L.R. The pros and cons of rewarding social responsibility at the top. Hum. Resour. Manag. 2009, 48, 959-971. [CrossRef]

114. SBTi. Ambitious Corporate Climate Action; Science Based Targets: 2021. Available online: https://sciencebasedtargets.org/ (accessed on 22 December 2021).

115. Maas, K. Do corporate social performance targets in executive compensation contribute to corporate social performance? J. Bus. Ethics 2018, 148, 573-585. [CrossRef]

116. Kolk, A.; Perego, P. Sustainable bonuses: Sign of corporate responsibility or window dressing? J. Bus. Ethics 2014, 119, 1-15. [CrossRef]

117. Derchi, G.B.; Zoni, L.; Dossi, A. Corporate social responsibility performance, incentives, and learning effects. J. Bus. Ethics 2021, 173, 617-641. [CrossRef]

118. Flammer, C.; Hong, B.; Minor, D. Corporate governance and the rise of integrating corporate social responsibility criteria in executive compensation: Effectiveness and implications for firm outcomes. Strateg. Manag. J. 2019, 40, 1097-1122. [CrossRef]

119. Martin-Rios, C. Innovative management control systems in knowledge work: A middle manager perspective. J. Manag. Control 2016, 27, 181-204. [CrossRef]

120. Hill, C.W.; Jones, T.M. Stakeholder-agency theory. J. Manag. Stud. 1992, 29, 131-154. [CrossRef]

121. Jo, H.; Harjoto, M.A. Corporate governance and firm value: The impact of corporate social responsibility. J. Bus. Ethics 2011, 103, 351-383. [CrossRef]

122. Holmstrom, B.; Milgrom, P. Multitask principal-agent analyses: Incentive contracts, asset ownership, and job design. JL Econ. Org. 1991, 7, 24. [CrossRef]

123. Cai, Y.; Jo, H.; Pan, C. Vice or virtue? The impact of corporate social responsibility on executive compensation. J. Bus. Ethics 2011, 104, 159-173. [CrossRef]

124. Martin-Rios, C.; Ciobanu, T. Hospitality innovation strategies: An analysis of success factors and challenges. Tour. Manag. 2019, 70, 218-229. [CrossRef]

125. Derchi, G.B.; Burkert, M.; Oyon, D. Environmental management accounting systems: A review of the evidence and propositions for future research. In Accounting and Control for Sustainability; Emerald Group Publishing Limited: Bingley, UK, 2013 ; pp. 197-229.

126. Gatti, L.; Vishwanath, B.; Seele, P.; Cottier, B. Are we moving beyond voluntary CSR? Exploring theoretical and managerial implications of mandatory CSR resulting from the new Indian companies act. J. Bus. Ethics 2019, 160, 961-972. [CrossRef]

127. Matten, D.; Moon, J. "Implicit" and "explicit" CSR: A conceptual framework for a comparative understanding of corporate social responsibility. Acad. Manag. Rev. 2008, 33, 404-424. [CrossRef]

128. Martin-Rios, C.; Pasamar, S. Service innovation in times of economic crisis: The strategic adaptation activities of the top EU service firms. RED Manag. 2018, 48, 195-209.

129. Martin-Rios, C.; Parga, E. Service response to economic decline: Management innovation as enabler of organizational renewal. J. Bus. Res. 2016, 69, 2890-2900. [CrossRef]

130. Posner, B.; Kiron, D.; Toffel, M.; Unruh, G.C. How Caesars Entertainment is betting on sustainability. MIT Sloan Manag. Rev. 2013, $54,63$. 